\title{
Synchronization of Electronic Medical Record Implementation Guidelines in National E-Health Strategies
}

(Sinkronisasi Pedoman Pelaksanaan Rekam Medis Elektronik dalam Strategi E-Kesehatan Nasional)

Rezky Ami Cahyaharnita

email : rezkyami@yahoo.com

Health Law Masters Program, University of Muhammadiyah, Malang

\begin{abstract}
Medical records are made in writing, complete and clear or electronically. Medical records are the basis of medical services to patients. Paper medical records increase the amount of paper waste in Indonesia. A national e-health strategy is a comprehensive approach to efforts in the national health sector. Electronic medical records are more effective because of better time management. The formulation of the problem in this article covers the reasons, criteria, and implementation of electronic medical records. The research method used is descriptive qualitative research with a statute approach. The criteria for a good electronic medical record are integrated data from various sources, data collected at the service point, and supporting service providers in decision making. The expected electronic medical record is to be integrated with the health service facility information system program without neglecting the confidentiality aspect. Therefore, the government needs to make regulations on the technical implementation of electronic medical records.
\end{abstract}

Keywords: Electronic medical record, national e-health strategy, health services

\section{PENDAHULUAN}

Rekam medis merupakan bagian terpenting dari penunjang medis. Menurut Pasal 1 Permenkes Nomor 269 Tahun 2008, rekam medis adalah berkas tentang identitas pasien, pemeriksaan, pengobatan, tindakan dan pelayanan lain yang telah diberikan kepada pasien. Rekam medis harus dibuat secara tertulis, lengkap dan jelas atau secara elektronik. ${ }^{1}$ Rekam medis merupakan dasar untuk merencanakan dan menganalisis penyakit dalam upaya merencanakan pemberian pengobatan, perawatan dan tindakan medis yang harus diberikan kepada pasien. Kelengkapan berkas rekam medis akan meningkatkan kualitas pelayanan untuk melindungi tenaga medis dalam mencapai kesehatan masyarakat yang optimal. Pelaksanaan rekam medis seringkali mengalami kendala seperti tidak lengkap dalam pengisian, berkas rekam medis hilang, ruang penyimpanan terbatas dan distribusi lama. Rekam medis bersifat rahasia. Kesalahan dalam pembuatan atau ketiadaan rekam medis memiliki akibat hukum. ${ }^{2}$ Selain itu, rekam medis kertas akan menambah jumlah timbunan sampah kertas di indonesia. Menurut Masrida, 2017 tentang komposisi sampah, diketahui bahwa sampah kertas menempati posisi kedua dalam komposisi sampah anorganik yaitu sebanyak $15 \%{ }^{3}$ Oleh karena itu, pemerintah perlu mengatur kebijakan mengenai strategi sistem elektronik kesehatan sebagai upaya kelengkapan berkas rekam medis.

\footnotetext{
1 Pasal 1 dan 2 Permenkes No. 269 Tahun 2008

${ }^{2}$ Sudjana. 2017. Aspek Hukum Rekam Medis Atau Rekam medis elektronik sebagai alat bukti dalam transaksi terapeutik. VeJ Vol.3 No.2 Hal. 361.

${ }^{3}$ Masrida, R. 2017. Kajian Timbulan Dan Komposisi Sampah Sebagai Dasar Pengelolaan Sampah di Kampus II Universitas Bhayangkara Jakarta Raya. Abstrak.
} 
Pemerintah telah mengeluarkan Peraturan Menteri Kesehatan Republik Indonesia Nomor 46 Tahun 2017 tentang Strategi E-Kesehatan Nasional. Hal ini merupakan upaya pendekatan secara menyeluruh untuk perencanaan, pengembangan, implementasi, dan evaluasi pemanfaatan teknologi informasi dan komunikasi di bidang kesehatan secara nasional. EKesehatan merupakan upaya mengintegrasikan berbagai sistem layanan kesehatan sehingga memungkinkan pertukaran data, informasi, dan pengetahuan. ${ }^{4} \mathrm{Hal}$ ini tentu mempermudah dalam penyimpanan, pencarian dan kelengkapan berkas rekam medis. Sistem e-kesehatan mendukung kelengkapan pelayanan kesehatan sehingga dapat terhindar dari masalah hukum maupun sebagai bukti dalam menghadapi kasus hukum.

Rekam medis elektronik adalah catatan medis seumur hidup pasien dalam format elektronik tentang informasi kesehatan seseorang yang dituliskan oleh satu atau lebih petugas kesehatan secara terpadu dalam tiap kali pertemuan antara petugas kesehatan dengan klien. ${ }^{5}$ Dalam peraturan perundang-undangan di Indonesia, rekam medis elektronik diperbolehkan. Dalam Permenkes No. 269 Tahun 2008 mengenai rekam medis disebutkan bahwa rekam medis dapat berbentuk elektronik. Rekam medis elektronik lebih efektif karena manajemen waktu akan lebih baik terutama dalam pelayanan kesehatan. Hal ini juga berdampak bahwa jumlah pegawai yang diperlukan tidak banyak sehingga dapat mengurangi pengeluaran dari suatu fasilitas kesehatan. ${ }^{6}$ Era jaminan kesehatan nasional menyebabkan peningkatan jumlah pasien di berbagai fasilitas kesehatan. Peningkatan tersebut berdampak pada meningkatnya tugas perekam medis dalam penyimpanan, pencarian dan kelengkapan arsip. Dengan jumlah karyawan yang tetap namun terjadi peningkatan tugas maka risiko kekeliruan dan tidak teliti akan semakin meningkat. Hal ini merupakan dasar perlunya suatu fasilitas kesehatan dalam memberlakukan rekam medis elektronik. Pemerintah Indonesia telah mendukung pengadaan rekam medis elektronik melalui Undang-Undang tentang rekam medis, strategi e-kesehatan nasional dan informasi teknologi. Namun, dalam pelaksanaannya masih terdapat beberapa hal yang perlu disempurnakan. Oleh karena itu, perlu mengetahui lebih lanjut tentang sinkronisasi pedoman pelaksanaan rekam medis elektronik dalam strategi e-kesehatan nasional.

\section{PERUMUSAN MASALAH}

Rumusan masalah dalam artikel ini adalah sebagai berikut :

1. Mengapa diperlukan rekam medis elektronik?

2. Bagaimana kriteria rekam medis elektronik yang dapat mendukung kualitas pelayanan kesehatan dan keselamatan pasien?

3. Bagaimana pelaksanaan rekam medis elektronik sesuai dengan peraturan hukum yang berlaku agar dapat mewujudkan strategi e-kesehatan nasional ?

\footnotetext{
4 Permenkes No. 46 Tahun 2017 tentang Strategi E-Kesehatan Nasional.

${ }^{5}$ Potter dan Perry, Fundamental of Nursing 7th Edition, Missouri, St.Louis, 2009.

${ }^{6}$ Gemala Hatta, Paradigma Baru Rekam Medis : Manajemen Informasi Kesehatan, Makalah seminar sehari Rekam Kesehtan Elektronik, Jakarta, 2005.
} 


\section{METODE PENELITIAN}

Metode penelitian yang digunakan adalah penelitian kualitatif deskriptif dengan pendekatan statute approach. Pendekatan statute approach dilakukan dengan menelaah semua peraturan perundang-undangan yang bersangkut paut dengan permasalahan (isu hukum) yang sedang dihadapi. Pendekatan perundang-undangan ini misalnya dilakukan dengan mempelajari konsistensi / kesesuaian antara Undang-Undang Dasar dengan Undang-Undang yang lainnya.

\section{PEMBAHASAN}

Rekam medis merupakan bagian penunjang medis yang penting. Beberapa dasar hukum positif telah mengatur tentang rekam medis. pasal 46 dan pasal 47 Undang- Undang No. 29 tahun 2004 tentang Praktik Kedokteran, disebutkan bahwa rekam medis adalah berkas yang berisikan catatan dan dokumen tentang identitas pasien, pemeriksaan, pengobatan, tindakan dan pelayanan lain yang telah diberikan kepada pasien. ${ }^{7}$ Ketentuan lebih lanjut mengenai pelaksanaan rekam medis telah diatur dalam Permenkes No. 269 tahun 2008 tentang rekam medis. Dalam pasal 2 ayat (1) disebutkan bahwa rekam medis dapat dibuat secara elektronik. ${ }^{8}$ Rekam medis merupakan sarana perlindungan hukum bagi rumah sakit, dokter, pasien yang berpegang pada garis kebijaksanaan umum yang menjadi landasan dan sekaligus tujuan dari politik hukum di Indonesia. ${ }^{9}$ Kerahasiaan dan penyimpanan berkas rekam medis merupakan kewajiban rumah sakit. ${ }^{10}$ Peraturan Menteri Kesehatan Nomor 269 Tahun 2008 Tentang RM, menjelaskan bahwa " RM adalah berkas yang berisi catatan dan dokumen antara lain identitas pasien, hasil pemeriksaan, pengobatan yang telah diberikan, serta tindakan dan pelayanan lain yang telah diberikan kepada pasien. Catatan merupakan tulisan-tulisan yang dibuat oleh dokter atau dokter gigi mengenai tindakan-tindakan yang dilakukan kepada pasien dalam rangka pelayanan kesehatan. Sedangkan dokumen adalah catatan dokter, dokter gigi, dan/atau tenaga kesehatan tertentu, laporan hasil pemeriksaan penunjang, catatan observasi dan pengobatan harian dan semua rekaman, baik berupa foto radiologi, gambar pencitraan (imaging) dan rekaman elektro diagnostik. ${ }^{11}$ Peningkatan jumlah pasien mengakibatkan peningkatan pencatatan laporan rekam medis. langkah untuk efisiensi dan efektivitas kerja adalah dengan melaksanakan rekam medis elektronik. Namun, landasan hukum yang mengatur tentang teknik pelaksanaan rekam medis elektronik belum ada.

Rekam medis elektronik terdapat dalam sistem yang secara khusus dirancang untuk mendukung pengguna dengan berbagai kemudahan fasilitas untuk kelengkapan dan keakuratan data, memberi tanda waspada, peringatan, memiliki sistem untuk mendukung keputusan klinik dan menghubungkan data dengan pengetahuan medik serta alat bantu lainnya. Hal- hal yang dapat disimpan dalam rekam medik elektronik berupa teks (kode, narasi, report), gambar (komputer grafik, gambar yang di-scan, hasil foto rontgen digital, suara (suara jantung, suara paru), video (proses operasi). Berdasarkan National Alliance for Health Information Technology tahun 2008, rekam medik elektronik adalah rekaman/catatan elektronik tentang informasi terkait kesehatan (health-related information) seseorang yang yang dibuat, dikumpulkan, dikelola, digunakan dan dirujuk oleh dokter atau tenaga

\footnotetext{
7 Pasal 46 dan 47 UU No. 29 Tahun 2004

${ }^{8}$ Permenkes No. 269 Tahun 2008

9 Retnowati, A. 2013. Politik Hukum Dalam Menata Rekam Medis. hal. 144-153

${ }^{10}$ Permenkes Nomor 40 Tahun 2018 tentang Kewajiban Rumah Sakit dan Kewajiban Pasien.

${ }^{11}$ Permenkes No. 269 Tahun 2008 Pasal 6 dan 7
} 
kesehatan yang berhak (authorized) di satu organisasi pelayanan kesehatan. Hal-hal yang perlu diperhatikan untuk menunjang infrastruktur yang berkaitan dengan rekam medis elektronik meliputi sistem administrasi, finansial/keuangan, data klinis dari unit-unit, pengintegrasian data, repository (Gudang Data) dan rules engine. Repository merupakan infrastruktur yang memusatkan data dari berbagai komponen lain atau cara lain untuk mengintegrasikan data. Rules Engine merupakan infrastruktur yang menyediakan program logis yang dapat dipakai untuk menunjang keputusan seperti; kewaspadaan dan pernyataan, daftar permintaan (Order Set) dan protokol klinis. Rekam Medik Elektronik (RME) merupakan sistem informasi yang memiliki framework lebih luas dan memenuhi satu set fungsi. Rekam Medik Elektronik (RME) yang baik harus memenuhi kriteria sebagai berikut:

a. Mengintegrasikan data dari berbagai sumber (Integrated Data From Multiple Source).

b. Mengumpulkan data pada titik pelayanan (Capture Data At The Point Of Care).

c. Mendukung pemberi pelayanan dalam pengambilan keputusan (Support Caregiver Decision Making). ${ }^{12}$

Pelaksanaan rekam medis elektronik mendukung pemerintah dalam mewujudkan strategi ekesehatan nasional. Berdasarkan Peraturan Menteri Kesehatan Republik Indonesia Nomor 46 Tahun 2017 tentang Strategi E-Kesehatan Nasional, rekam medis elektronik merupakan komponen dari e-kesehatan care application. Hal ini menandakan bahwa rekam medis elektronik merupakan aplikasi yang mendukung perawatan dan penanganan layanan kesehatan. Pelaksanaan e-kesehatan memerlukan bantuan dan kesiapan dari berbagai pihak. Sumber daya manusia merupakan hal utama yang harus ditingkatkan untuk pemanfaatan, pengembangan dan implementasi teknologi informasi dan komunikasi. Pembinaan, pemantauan dan evaluasi terhadap strategi e-kesehatan nasional dilaksanakan oleh Kementerian Kesehatan, Dinas Kesehatan Provinsi, dan Kabupaten / Kota secara berjenjang sesuai tugas, fungsi dan kewenangan masing-masing. Implementasi e-kesehatan telah menjadi komitmen global dalam World Health Assembly (WHA) pada tahun 2010. E-Kesehatan adalah pemanfaatan teknologi informasi dan komunikasi untuk pelayanan dan informasi kesehatan, utamanya untuk meningkatkan kualitas pelayanan kesehatan dan proses kerja efektif efisien. Beberapa fasilitas kesehatan di Indonesia telah melaksanakan e-kesehatan. Namun, terdapat banyak kekurangan dalam pelaksanaannya. Hasil assessment Commission of Information and Accountability (COIA) pada tahun 2013 menunjukkan bahwa ada 6 komponen implementasi e-kesehatan yang masih memerlukan perbaikan yaitu, kebijakan, infrastruktur, aplikasi, standar, tata kelola, dan pengamanan. ${ }^{13}$

Kemajuan sistem informasi dan teknologi mendorong peningkatan kualitas pelayanan kesehatan melalui sistem elektronik. Perkembangan layanan kesehatan dengan memanfaatkan sistem elektronik perlu didukung oleh berbagai pihak. Pelaksanaan ekesehatan merupakan satu upaya dalam mencegah peningkatan kasus human or process errors. Beberapa negara telah memiliki standar khusus yang mengatur pelaksanaan rekam medis elektronik yang terintegrasi, misalnya Brazil. Brazillian Federal Council of Medicine (CFM) menyetujui penggunaan rekam medis elektronik dengan berbagai pertimbangan. Penggunaan rekam medis elektronik dapat mengurangi kepadatan tempat penyimpanan berkas, mengurangi waktu tunggu distribusi, dan mengurangi jumlah penggunaan kertas. CFM menyetujui standar digitalisasi teknis dan penggunaan sistem komputerisasi untuk penyimpanan dan penanganan dokumen dari catatan pasien dan pengurangan penggunaan

${ }^{12}$ Setyawan 2017. Handout Mata Kuliah Rekam Medis

${ }^{13}$ Lampiran Permenkes No. 46 Tahun 2017 
kertas yang natinya akan diwujudkan berupa informasi kesehatan yang diidentifikasi. Tujuan yang ingin dicapai adalah catatan pasien berupa laporan digital. Berkas digital dari catatan digitalisasi pasien harus dikendalikan oleh Manajemen Dokumen Elektronik. Penggunaan sistem terkomputerisasi untuk penyimpanan dan penanganan pasien berupa catatan dan dapat digunakan untuk bertukar informasi kesehatan asalkan memenuhi persyaratan keamanan dan kerahasiaan. Tanda tangan digital dan terstandarisasi harus sesuai sertifikasi digital yang berlaku di suatu negara. Bahkan di Brazil telah ditetapkan peraturan khusus menggunakan meterai sesuai standar digital untuk surat elektronik berbentuk suatu perjanjian. Negara Brazil memberlakukan pemusnahan data rekam medis elektronik dalam batas waktu 20 tahun. Data tersebut nantinya akan dihapus secara permanen bila melewati batas waktu penyimpanan 20 tahun. ${ }^{14}$

Pelaksananaan rekam medis elektronik sangat penting diterapkan dalam era jaminan kesehatan nasional. Hal ini disebabkan adanya sistem rujukan sehingga penggunaan teknologi informasi dan komunikasi dierlukan untuk mendukung operasional dan pelayanan kesehatan terhadap pasien. Setiap fasilitas kesehatan diharapkan memiliki penataan sistem data transaksional dalam fasilitas pelayanan kesehatan (seperti SIMPUS, SIMRS). Aspek keamanan informasi secara berkesinambungan akan berkembang dalam lingkungan yang serba elektronik. Sejalan dengan kemajuan teknologi informasi dan komunikasi, standarisasi e-kesehatan perlu segera dilaksanakan, terlebih lagi implementasi yang melibatkan layanan kesehatan, badan penjamin (BPJS atau asuransi kesehatan), masyarakat dan regulator. ${ }^{15}$

\section{KESIMPULAN}

Pelayanan kesehatan dalam era industri 4.0 memerlukan peningkatan mutu pelayanan medis dan penunjang medis. Rekam medis merupakan bagian penting dalam bidang penunjang medis. Rekam medis elektronik dapat memberikan informasi kesehatan secara cepat dan lengkap sehingga proses terapeutik pada pasien berjalan dengan baik dan meningkatkan mutu pelayanan kesehatan. Kriteria rekam medis elektronik yang baik adalah data terintegrasi dari berbagai sumber, data terkumpul pada titik pelayanan, dan dapat mendukung pemberi pelayanan dalam pengambilan keputusan. Rekam medis elektronik mendukung upaya pemerintah dalam menerapkan strategi e-kesehatan nasional. Pelaksanaan rekam medis elektronik yang diharapkan adalah dapat terintegrasi dengan program sistem informasi fasilitas pelayanan kesehatan. Hal tersebut dapat memudahkan pengolahan data, penelitian, pendidikan, dan penghitungan statistik yang digunakan dalam pelayanan kesehatan tanpa mengabaikan aspek kerahasiaannya.

\section{SARAN}

Rekam medis elektronik merupakan upaya mewujudkan strategi e-kesehatan nasional. Hal ini perlu didukung oleh peningkatan sumber daya manusia tentang sistem informasi dan teknologi kesehatan. Kriteria rekam medis yang baik sudah tercantum dalam dasar hukum yang berlaku. Namun, dalam pelaksanaannya seringkali ditemukan berbagai kendala. Oleh karena itu, pemerintah perlu membuat peraturan khusus yang mengatur tentang teknis pelaksanaan rekam medis elektronik.

\footnotetext{
${ }^{14}$ Salomi. 2017. Document Management and Process Automation in a Paperless Healthcare Institution. Introduction

${ }^{15}$ Lampiran Permenkes No. 46 Tahun 2017 hal. 23
} 


\section{DAFTAR PUSTAKA}

Mulasari, L. (2012). Kebijakan Formulasi Tentang Tindak Pidana Kesusilaan di Dunia Maya dalam Perspektif Hukum Islam. MMH, Jilid 41. 98 - 109.

Kementerian Kesehatan RI. (2008). Peraturan Menteri Kesehatan Republik Indonesia Nomor 269/MENKES/PER/III/2008 Tentang Rekam Medis.

Sudjana. (2017). Aspek Hukum Rekam Medis Atau Rekam medis elektronik sebagai alat bukti dalam transaksi terapeutik. VeJ Vol.3 No.2. Hal. 359-383.

Masrida, R. (2017). Kajian Timbulan Dan Komposisi Sampah Sebagai Dasar Pengelolaan Sampah di Kampus II Universitas Bhayangkara Jakarta Raya. Journal of Env. Engineering \& Waste Management, Vol. 2, No. 2, Oktober 2017: 69-78.

Kementerian Kesehatan RI. (2017). Peraturan Menteri Kesehatan Republik Indonesia Nomor 46 Tahun 2017 tentang Strategi E-Kesehatan Nasional.

Perry, A.G., \& Potter, P.A. (2009). Fundamental of nursing. Seventh Edition. St. Louis Missouri : Mosby Inc.

Hatta,G. (2005). Paradigma Baru Rekam Medis : Manajemen Informasi Kesehatan. Makalah seminar sehari Rekam Kesehatan Elektronik. Jakarta.

Presiden Republik Indonesia. (2004). Undang-Undang Republik Indonesia Nomor 29 Tahun 2004 Tentang Praktik Kedokteran.

Retnowati, A. 2013. Politik Hukum Dalam Menata Rekam Medis Sebagai Sarana Perlindungan Hukum Terhadap Rumah Sakit, Dokter dan Pasien. Yustisia Vol. 2 No.2 Mei-Agustus 2013. Hal. 144-153.

Kementerian Kesehatan RI. (2017). Peraturan Menteri Kesehatan Republik Indonesia Nomor 40 Tahun 2018 tentang Kewajiban Rumah Sakit dan Kewajiban Pasien.

Setyawan, D. (2017). Handout Mata Kuliah Sistem Informasi Kesehatan Rekam Medis Elektronik. Poltekkes Surakarta.

Salomi, M., Maciel, R. (2017). Document Management and Process Automation in a Paperless Healthcare Institution. Technology and Investment, 2017, 8, Hal. 167-178. 